\title{
SZABÓ Anna
}

\section{A munkavállalói elkötelezettség növelésének hatása és lehetőségei}

\section{Bevezetés}

A munkavállalói elkötelezettség definiálása után alátámasztom, hogy miért is hasznos az elkötelezettség a dolgozók és a vállalatok számára, hogyan hozható kapcsolatba a jobb üzleti eredményekkel, tehát miért éri meg egyáltalán odafigyelni rá, és a kialakításába erőforrásokat fektetni.

A tanulmány további részében a munkavállalói elkötelezettség kialakulását boncolgatom. Azonosítom, hogy mik azok az úgy nevezett mozgatórugók, amelyek az elkötelezettséget keletkezésében szerepet játszanak, és amelyek a munkavállalók számára a legfontosabb elkötelezettségnövelő tényezők, valamint bemutatom, hogy milyen szempontokat érdemes a vállalatoknak figyelembe venni mielőtt az elkötelezettség erősítésének érdekében akciókat terveznének vagy hajtanának végre.

\section{A munkavállalói elkötelezettség fogalma}

Az elkötelezettség nem új keletű kifejezés, az ezredforduló óta pedig kifejezetten népszerűvé, sőt talán már közhellyé is vált. A munkaadók számára vonzó elképzelés a munkavállalók elkötelezettségének kialakítása, ami többek között a kilépésekre is megoldást jelenthet. Az elkötelezettség azonban nem a maradási hajlandóságot jelenti, pontosabban nem csupán azt. Véleményem szerint, annak ellenére, hogy sokat hangoztatott fogalom, kevesen vannak tisztában az elkötelezettség igazi jelentésével és valódi hatásaival.

Talán éppen a népszerűsége miatt, de a munkavállalói elkötelezettségnek nincs általánosan elfogadott definíciója a szakirodalomban. Sokan, különböző módon definiálták, köztük akadémikusok, kutatók, tanácsadó cégek, attól függően, hogy miként azonosították a fogalmat.

Egyes meghatározások szerint az elkötelezettség egyfajta érzés. Az egyéni bevonódás, elégedettség és a munka iránti lelkesedés (Harter és társai, 2002). Truss és társai (2006) úgy gondolják az elkötelezettség annyit tesz, hogy pozitívan érzel a munkád iránt. Az elkötelezett dolgozók azok, akik szenvedélyesek a munkájuk iránt, energikusak, és akik teljesen elmerülnek benne. (Armstrong - Taylor, 2014)

Mások az egyén és a szervezet között kialakult kapcsolatként határozzák meg. Így vélekedik erről a Chiumento (2004) szervezet is, ami definíciójában az elkötelezettséget egy pozitív, kétirányú kapcsolatként azonosítja, ahol mind két fél - a munkaadó és a munkavállaló egyaránt tisztában van a saját és a másik szükségleteivel, igényeivel, és annak a módjával, hogyan lehet azokat teljesíteni. Az elkötelezett munkavállalók és szervezetek az elvártnál többet teljesítenek, mivel látják azokat az előnyöket, amik a kapcsolatba történő befektetésből származnak. (Armstrong, (2006)

Fellelhetőek olyan meghatározások is, amik szerint az elkötelezettség viszonzásként fogható fel. Ezek a meghatározások a szociális csere elméletén alapulnak. Saks (2006) szerint az egyének a különböző elkötelezettségi szintekkel fizetik vissza azokat az erőforrásokat, amiket a szervezettől kapnak. Sparrow (2009) szerint a munkavállalók hűsége, elkötelezettsége és 
önkéntes erőfeszítései mind a munkavállalói viszonzás valamely formái a jó munkáltató irányába. (Armstrong - Taylor, 2014)

A munkavállalói elkötelezettségről rendszeresen felmérést végző és egyéb tanácsadó cégek az elkötelezettséget mértékként azonosították. Ezt bizonyítja a KPMG (2011) könyvvizsgáló és adótanácsadó vállalat által adott meghatározás is, miszerint a munkavállalói elkötelezettség a dolgozó szervezethez, munkahelyi kultúrához, szerepéhez, kollégáihoz való kapcsolódását és kapcsolatát méri. Az elkötelezettség szintje pozitívan vagy negatívan befolyásolja a munkavállalók arra való hajlandóságát, hogy extra erőfeszítéseket tegyenek munkájuk során, újítók legyenek és elősegítsék a vállalatot a stratégia elérésében.

A Towers Perrin tanácsadó cég úgy definiálta a munkavállalói elkötelezettséget, mint a munkavállalók hajlandósága és képessége, hogy hozzájáruljanak a vállalati sikerhez. Más szóval az elkötelezettség annak a mértéke, hogy a munkavállalók önszántukból mennyi extra erőfeszítést, energiát, kreativitást és szenvedélyt hajlandóak beletenni a munkájukba. (Towers Perrin, 2008)

A dolgozói elkötelezettség vizsgálatok egyik szakértő tanácsadó cége, az Aon Hewitt a rendszeresen készített felmérései alapján a munkavállalói elkötelezettséget a munkahelyi környezetre adott emocionális vagy viselkedési reakcióként határozta meg. Emocionális szinten ez motivációban, lelkesedésben, a feladatokra fordított figyelemben jelenik meg, míg viselkedési szinten, három módon nyilvánulhat meg (Aon Hewitt, 2013):

- say: a munkavállaló jó dolgokat mond a szervezetről mind a munkatársaknak, mind a potenciális munkavállalóknak vagy ügyfeleknek

- stay: a munkavállaló úgy érzi a vállalathoz tartozik, ezért maradni szeretne, nem tervez munkahelyet változtatni

- strive: a munkavállaló hajlandó és törekszik is arra, hogy az elvárton felül teljesítsen, több energiával, kreativitással áll a feladathoz, mindent megtéve annak elvégzése érdekében, hozzájárulva ahhoz, hogy a vállalat elérje a céljait

Attól függően, hogy mi az elköteleződés tárgya, mi iránt vagy mellett elkötelezett egy egyén, az elkötelezettségnek több fajtáját, aspektusát is meg tudjuk különböztetni.

Amikor a dolgozót érdekli és izgatott az iránt, amit csinál, és jobban kötődik a munkájához, mint magához a szervezethez ahol dolgozik, akkor munkaköri vagy szakmai elkötelezettségröl beszélünk. Ez a fajta elkötelezettség akkor is fenn állhat, amikor a szervezet iránt nem elkötelezett az egyén. Munkaköri vagy szakmai elköteleződést leggyakrabban a tudásmunkásoknál lehet megtapasztalni, akik a szakmájuk iránti lelkesedés miatt válnak motiválttá a magasabb teljesítmény elérésében. (Armstrong, 2006)

Szervezeti elkötelezettségről akkor beszélünk, amikor az egyének azonosulnak és kötődnek a szervezet egészéhez. Robinson és társai (2004) az elkötelezettség szervezeti aspektusát úgy határozták meg, mint a munkavállaló pozitív attitúdje a vállalat és annak értékei felé.

Armstrong és Taylor (2014) szerint az elkötelezettség legjobb magyarázatot adó megközelítését az jelenti, ha felismerjük, hogy az mind a munkaköri, mind a szervezeti elkötelezettséget magába foglalja.

A meghatározások világossá teszik, hogy annak ellenére, hogy a köznyelvben sokszor a maradással, hűséggel, elégedettséggel, motiváltsággal azonosítják, vagy akár még szinonimaként is használják, a munkavállalói elkötelezettség nem azonos ezekkel a 
fogalmakkal. Nem csupán egy jó érzelmi állapot, mint az elégedettség, és a motivált dolgozóktól eltérően az elkötelezett dolgozók nem csak azért tesznek erőfeszítéseket, mert esélyt éreznek arra, hogy azok kívánatos jutalomra vezetnek (Koncz, 2013). Továbbá sem a maradással, sem a hűséggel nem azonos az elkötelezettség jelentése. Ha egy dolgozó a vállalatnál marad, az nem jelenti azt, hogy elkötelezett is. Önmagában a hűség sem jelenti az elvárton felül végzett erőfeszítést, a vállalati célok teljesítése érdekében végzett teljesítést, ami versenyképességet és tartós versenyelőnyt jelenthet. Az elkötelezettség viszont igen, és éppen ez teszi a fogalmat ennyire vonzóvá.

\section{Munkavállalói elkötelezettség következményei}

A legtöbb meghatározás a következményeiben megragadva definiálja az elkötelezettséget. Ennek oka az lehet, hogy az elkötelezettség kihatásai azok, amik igazán fontosak. Akárhogyan is értelmezzük is, egy dolog közös a felfogásokban: az elkötelezettség mindegyikben pozitív kihatásokat jelent. Ezek a kedvező következmények vonatkozhatnak a munkavállalóra és a munkáltatóra egyaránt.

\section{A munkavállalót érintő következmények}

A munkavállalói elkötelezettség magas szintje a munkavállaló számára előnyös. Jobban érzi magát egy olyan környezetben, amihez érzelmileg is kötődik. Ugyan az elkötelezett dolgozó az elvárton felül teljesít, de azt önszántából teszi, nem pedig kényszerből. Az olyan erőfeszítések, amiket a dolgozó önakaratból vállal, akár fizikaiak akár mentálisak, sokkal kevésbé lesznek megterhelőek a számára.

Kutatások alátámasztották, hogy az elkötelezettség korrelál egyéb, a munkavállaló munkára adott érzelmi reakciójával. Minél magasabb egy dolgozó elkötelezettsége, annál magasabb a maradási szándéka, a hűsége, a motivációja. Ezen kívül több az önbizalma a saját képességeiben, abban hogy változást tud elérni a szervezetében, magasabb a munkahelyi környezet feletti kontroll érzetének szintje, nagyobb a mértéke a csapatmunkában való részvételének, a szervezettel való azonosulásának. Az is bizonyított, hogy az elkötelezettebb dolgozó kisebb mértékben tapasztal szerepkonfliktust, illetőleg stresszt. (Storey és társai, 2009)

\section{A munkáltatót érintő következmények}

Guest (2013) szerint az elkötelezettség azért vonzó, mert nyilvánvalóan jó dolog. A menedzserek számára ideális elképzelés, hogy elkötelezett munkavállalóik vannak.

A munkavállalói elkötelezettségnek számos olyan a munkáltató szempontjából előnyös következménye van, amelyekkel szinte minden kutató egyetért, ilyen a nagyobb megtartási arány, kevesebb hiányzás, vállalati célok és stratégia jobb megértése.

Megtartás: A munkavállalói elkötelezettség és a maradási hajlandóság között pozitív korreláció van. Minél jobban növekszik az elkötelezettség, annál jobban csökken annak a valószínűsége, hogy a munkavállalók elhagyják a szervezetet. Mivel az elkötelezettebb dolgozók érzelmileg is kapcsolódnak a szervezethez, ezért talán evidensnek tekinthető, hogy hüségesebbek is.

Megértés: Tanulmányok alapján az elkötelezett dolgozók átlag felett megértik a szervezet céljait és a lépéseket, amiket azok elérése érdekében tesz. Felismerik, hogy munkájuk milyen 
szerepet tölt be a vállalati stratégiában, hogyan járul hozzá a szervezeti sikerhez. Érdekli őket a vállalat jövője ezért hajlandóak extra erőfeszítéseket tenni munkájuk során. A magasan elkötelezett dolgozók továbbá nagyobb mértékben bíznak meg a vezetőkben, nem kételkednek azok döntéseiben.

Hiányzás: Az elkötelezett dolgozók bizonyítottan kevesebbet hiányoznak és kevesebb betegszabadságot vesznek ki. A Gallup 2003-as felmérése alapján az elkötelezett dolgozók az Egyesült Királyságban átlagosan évente 2,69 nap beteg szabadságot vettek ki, míg az el nem kötelezettek 6,19 napot (KPMG, 2011). Ez azt jelenti, hogy az el nem kötelezett dolgozók kétszer annyit hiányoznak, ami jelentős költséget jelent egy szervezetnek.

Üzleti eredmény: Egyre több kutatás alátámasztja, hogy a munkavállalói elkötelezettség közvetlenül vagy közvetve összefüggésben áll a vállalati siker és az üzleti eredmény szempontjából olyan fontos tényezőkkel, mint a magasabb termelékenység és értékesítés, gyorsabb üzleti növekedés, alacsonyabb toborzási költségek.

A munkavállalói elkötelezettség annak a mértéke, hogy mennyire hajlandóak a munkavállalók extra erőfeszítéseket tenni, elvárton felül dolgozni. Alfes és társai (2010) szerint az elkötelezett munkavállalók a többieknél jobban teljesítenek, innovatívabbak, a kapott munkamennyiséget kibírhatóbbnak és teljesíthetőbbnek érzik (Armstrong - Taylor, 2014). Az elkötelezett dolgozók kevesebb hiba számot és jobb termék, szolgáltatás minőséget produkálnak.

Az elkötelezettség közvetve az értékesitési eredményekre is befolyással lehet. Az elkötelezett dolgozók 70 százaléka állítja, hogy megérti a vásárlók szükségleteit, míg az el nem kötelezettek közül 17 százaléka gondolja ugyan ezt (KPMG, 2011). A Towers Perrin kutatásai is rávilágítanak arra, hogy az elkötelezett dolgozók jobban odafigyelnek az ügyfelekre, vásárlókra, ami növelheti a vállalat bevételeit. Ez különösen a szolgáltató szektorban jelentős, ahol a megfelelő munkavállalói magatartás erősítheti a fogyasztói elégedettséget és húséget.

A munkavállalói elkötelezettség csökkentheti a költségeket is. A jobb megtartási arányok miatt alacsonyabbak a toborzási költségek, a kevesebb hiányzás úgyszintén költségmegtakarítást jelent. Az elkötelezett dolgozók büszkék a szervezetre és szívesen ajánlják, ezáltal a vállalat hírnökei. A jó vállalati hírnév jobb munkaerő-piaci pozícióhoz vezethet, ami vonzza a tehetséges embereket, szintén alacsonyabb toborozási és oktatási költségeket jelentve a vállalatnak.

Beláthatjuk, hogy a munkavállalói elkötelezettség fontossága nem csupán közhely, a vállalatok számára tényleg hasznos lehet, akár az üzleti teljesítmény, akár a munkaerő-piaci helyzet szempontjából. Azt viszont nem szabad elfelejteni, hogy az elkötelezettség egy „kétirányú kapcsolat”. Ahhoz, hogy a munkavállalók igazán elkötelezettek legyenek a munkáltatónak tennie is kell valamit.

\section{Munkavállalói elkötelezettség kialakítása}

Storey és társai (2009) véleménye szerint az elkötelezettséget úgy kell kezelni, mint minden HR beavatkozást és folyamatot: stratégiai megközelítéssel, programmal. A munkavállalói elkötelezettség erősítését célzó akciók kialakítása előtt az alábbi három pontot érdemes a vállalatoknak figyelembe venniük:

- Mi befolyásolja az elkötelezettséget? 
- Kiket akar egy vállalat elkötelezni?

- Mi iránt és milyen viselkedésre akarja őket elkötelezni?

\section{Munkavállalói elkötelezettség mozgatórugói}

A vállalatok számára az első és talán legfontosabb lépés, hogy megismerjék és tudatosítsák azokat a tényezőket, amik az elkötelezettség kialakulásában kulcsszerepet játszanak, tisztában legyenek azokkal a mozgatórugókkal, amik elköteleződésre késztetik a munkavállalókat a szakmájuk vagy a szervezetük iránt. Ezek a tényezők megértésének hiánya egyrészt a munkavállalói elkötelezettség erősítésébe fektetett erőforrások pazarlását jelenti, másrészt elveszik a magas munkavállalói elkötelezettségből eredő üzleti eredmények és a tartós versenyképesség, versenyelőny kialakításának lehetősége is.

A szakirodalom és a különböző felmérések az elkötelezettség növelésében szerepet játszó tényezőket különböző módon hívják, illetve csoportosítják. Egyesek mozgatórugóknak nevezték el, mások előzményekként, vagy az eléréséhez szükséges eszközökként azonosították. Az Aon Hewitt ezeket a tényezőket elégedettségi dimenzióknak nevezi, véleményük szerint ugyanis az elégedettség előfeltétele az elkötelezettségnek és a tényezőkkel való elégedettségük az, ami megalapozza a munkavállalók elkötelezettségét. A különböző csoportosításokat összevetve ${ }^{1}$ kilenc kategóriába, csoportba lehet sorolni az elkötelezettség növelésében szerepet játszó tényezőket:

Jövőkép: A dolgozók nagyobb valószínúséggel lesznek elkötelezve, ha ismerik a vállalat jövőképét és hosszú távú céljait, értik és elfogadják azokat, továbbá ha tisztában vannak azzal, hogy erőfeszítéseik hogyan segítik a vállalatot a céljai elérésében, illetve látják azt, hogyan járulnak vagy járulhatnak hozzá a vállalati sikerhez akár hosszabb távon akár a mindennapi munkájuk során. Még inkább nőhet az elköteleződés, ha azonosulni tudnak a vállalati célokkal és értékekkel, mert az által sajátjuknak tekintik azokat.

Lehetőségek: A vállalat nyújtotta lehetőségek mind elkötelezettség növelő hatásúak lehetnek. Ezek a lehetőségek vonatkozhatnak karrier előrelépésre, előmenetelre, tapasztalatszerzésre, személyes és szakmai fejlődésre (akár a jelenlegi munkakörben, akár a munkakörön túlmutatóan), tanulásra, képzési programokban való részvételre. Vonatkozhatnak a munkavállalói vélemények, aggodalmak kifejezésére nyújtotta nagyobb térre, vagy a döntési folyamatokban való részvételre. Jelenthetik azt is, hogy a dolgozók különböző munkakörökben és akciókban próbálhatják ki magukat, több feladatot végezhetnek, megmutatva az eltérő képességeiket és készségeiket.

Munka és feladatok: A munka milyensége, minősége is nagymértékben befolyásolja a dolgozói elkötelezettség szintjét. Az értelmes és érdekes munka, izgalmakkal, kihívásokkal és változatossággal teli feladatok általánosságban az elkötelezettség erősödéséhez vezetnek. Ha a munkavállaló úgy érzi, hogy munkája jelentőségteljes és fontos, a feladatok és a határidők ésszerűek és teljesíthetőek, akkor a megvalósításuk után büszkeség tölti el, ami növeli az elégedettséget és ez által az elkötelezettséget. Ezzel szemben a nagy munkaterhelés és munkahelyi nyomás elégedettség és elkötelezettségcsökkentő.

Önrendelkezés: Az elnyomottnak vagy irányítottnak érző emberekből nem lesz lelkes munkaerő, az ilyen légkör pedig nem táplálja az önkéntes erőfeszítéseket (Armstrong, Murlis, (2005)). Munkavállalói elkötelezettség szempontjából tehát fontos a dolgozóknak

\footnotetext{
${ }^{1}$ Storey és társai (2009), Crawford és társai (2013), Aon Hewitt és a Hay Group csoportosításait integráltam.
} 
nyújtott függetlenség, önállóság, a saját belátásuk szerinti munkavégzés és időbeosztás lehetősége, a felhatalmazás, a döntésekbe való bevonás, saját munkájuk feletti kontroll érzete. A szabadság erősíti a bizalom és megbecsülés érzését, ami növeli az elégedettséget, elkötelezettséget.

Szociális környezet: Az emberek életében alapvetően fontos a társadalmi környezet, ezért természetes, hogy a munkahelyi kapcsolatok, szociális viszonyok is szerepet játszanak abban, hogy egy dolgozó hogyan érzi magát, elköteleződik-e. Egyesek szerint például a vezetőknek van a legnagyobb felelőssége az elkötelezettség alakításában, az ő milyenségük, hozzáállásuk, minőségük az, ami végső soron befolyásolja a munkavállalók elkötelezettségét. A kollégákkal kialakított kapcsolatok szintén fontosak. A csapathoz való tartozás, együttmúködés, az, hogy a munkatársak mennyire hasonló tulajdonságokkal rendelkeznek, kialakultak-e barátságok a munkatársak között, a közösséghez tartozás érzete vagy éppen ellenkezőleg, a személytelen és antiszociális környezet mind befolyásolják az elkötelezettség szintjét.

Kommunikáció: A dolgozók vállalati ügyekről, célokról történő tájékoztatása, a dolgozók és a vezetők közötti kommunikáció lényegbevágó, hiszen nem vártható el a munkavállalóktól, hogy az elvárton felül teljesítsenek a vállalat sikeressége érdekében, ha nincsenek tisztában a vállalati célkitűzésekkel. Szintén fontos a munkavállalók véleménynyilvánítása, amitől jobban a szervezet részesének, értékesnek érzik magukat, a munkatársak közötti információáramlás, továbbá a dolgozóknak az őket érintő ügyekben történő tájékoztatása, a különböző felmérések eredményeinek kommunikálása, teljesítményük hatékonyságáról adott visszajelzések, illetve a javadalmazásukkal kapcsolatos információnyújtás.

Környezet: Ebbe a kategóriába tartoznak egyrészt a munkakörnyezettel kapcsolatos olyan tényezők, mint a munkahelyi és személyi biztonság, a fizikai munkakörnyezet és a használt eszközök, berendezések minősége, másrészt azok az elemek, amik a környezet támogató jellegére utalnak, például mennyire segíti a munka és magánélet közötti egyensúly kialakítását vagy csökkentik a káros stresszt.

Vállalati értékek és gyakorlatok: Elkötelezettség növelő tényezők lehetnek a vállalatok mindennapi működésük során alkalmazott olyan gyakorlatai és értékei, mint a sokszínűség kezelése, a teljesítménymenedzsment, az innováció mértéke, vásárlói fókusz, a tehetségek megtartása és kezelése, szervezeti értékek és viselkedések, kockázatmegosztás, de ide tartozik a szervezet elismertsége, jó híre vagy éppen hírhedtsége.

Javadalmazás és elismerés: Fontos elégedettségi terület a javadalmazás és elismerés. Ebbe beletartozik, hogy mennyire méltányosnak és igazságosnak érzik a kapott kompenzációs csomagot, ösztönzési eszközöket, versenyképesek-e a fizetések és juttatások, milyen a kapott változó bér, a vállalat értékeli-e a kiugró teljesítményt. Az anyagi mellett a nem anyagi elismerésnek is fontos szerepe van. Nagyobb valószínűséggel köteleződnek el a dolgozók olyan vállalatban és vállalat iránt, ahol megbecsülik és értékelik őt, ennek kifejezésének egyik módja pedig a verbális elismerés, szóbeli dicséret.

A csoportosítás jól alátámasztja, hogy gyakorlatilag bármi, ami a munkahelyi tapasztalatokkal, élményekkel, munkával vagy munkatársakkal kapcsolatos a munkavállalói elkötelezettség egyik lehetséges hajtóereje lehet.

Az viszont, hogy melyiknek van a legnagyobb hatása, melyik befolyásolja leginkább az elköteleződést, egyénenként változó, ahogyan az emberek szükségletei és igényei is 
eltérőek. Sőt Storey és társai (2009) kiemelik, hogy egy egyén érdekei is megváltozhatnak a karrier útja során. A munkáltatóknak azt kell azonosítania, hogy munkaerejének mely területek, hajtóerők a legfontosabbak, az elkötelezettség erősítését célzó programok megalkotásakor ugyanis ezekre kell fókuszálniuk.

Ezt a különböző elégedettség- és véleményfelmérésekkel, belső kutatásokkal tehetik meg. Ezekkel a felmérésekkel alapvetően nem lehet elkötelezettséget kialakítani, de jó alapot adhatnak arra vonatkozóan, hogy a mozgatórugók közül melyek a munkáltató számára a relevánsak.

Az Aon Hewitt tanácsadó cég a 2014-es felmérésében a munkahelyi tapasztalatok területeit az elkötelezettségben való statisztikai fontosságuk és a terület fejlesztésének lehetősége alapján rangsorolta. Ez alapján globálisan a következő kulcsterületeket találta 2013-ban az öt legfontosabb elkötelezettségnövelő tényezőnek:

1. Karrier lehetőségek

2. Teljesítménymenedzsment

3. Szervezeti hírnév

4. Fizetés

5. Kommunikáció

\section{Elkötelezni - kiket?}

A sorrend a globális általános eredményeket mutatja. A rangsor eltérő a különböző földrajzi régiókban, vállalatok között, sőt egy vállalaton belül, szegmensenként is. Ilyen szegmensek lehetnek többek között a munkavállalók kora, munkakörének funkciója vagy munkakörének a hierarchiában elfoglalt helye alapján képzett csoportok.

\section{A munkavállaló kora}

Napjainkban az aktív munkaerőt általában három csoportba szokták sorolni születése alapján. Az 1945 és 1960 között születetteket a Baby Boom, az 1960 és 1985 között születetteket X, míg az 1985 és 2000 között születetteket Y generációnak nevezik (Bokor és társai, 2009). A különböző generációs csoportok eltérő módon szocializálódtak, más az életstílusuk, szemléletük, így természetes, hogy az elkötelezettségük növekedésében is eltérő tényezők játszanak fontos szerepet. A fizetés például csak az $Y$ generációnak, az elismerés csak az $X$ generációnak jelent lényeges elégedettségi területet. Az innováció mind az X, mind a Baby Boomerek számára kiemelkedően fontos, a fiatalabb Y generációnak ennél lényegesebb a szervezeti hírnév. Nem csak a sorrend tér el a generációk között, de maga az elkötelezettség szintje is. A Baby Boomerek között volt a legnagyobb az elköteleződés szintje 66 százalékkal, míg az Y generációnál 56 százalékkal a legkevesebb. Átlagosan tehát az idősebbek elkötelezettebbek, mint a fiatalok.

\section{Munkaköri funkció, munka típusa}

A dolgozók munkakörének alapján képzett csoportok elkötelezettségnövelő tényezőinek rangsorában nagyobb a szóródás, mint a generációs csoportok között. A különböző munkaköri típusokban dolgozók számára lényeges területek rangsora, munkájukból adódóan szinte nyilvánvaló. A marketing és értékesítési szakemberek számára például a vállalati hírnév, márka és innováció a kiemelkedően fontosak, míg a mérnökök illetve a termelés, gyártás területén dolgozók számára a fizetés mellett a munkafolyamatok, elismerés, tanulási 
és fejlődési lehetőségek a fontos elégedettségi területek. A pénzügyi és adminisztrációs munkakörökben a többi szegmenstől eltérően a munkafeladatok is megjelentek, mint fontos tényezők.

\section{Munkakör szervezetbeli szintje}

A szervezeti hierarchiában elfoglalt hely alapján létrehozott szegmensek majdnem mindegyikében a legfontosabb tényező a karrier lehetőség volt. Ettől eltér a szakértői munkatársak rangsora, ahol az első helyen, megosztottan két tényező, a karrier- valamint a tanulás és fejlődési lehetőségek állnak, illetőleg a felső vezetés rangsora, ahol az első számú elégedettségi területet az elismerés jelenti. A magasabb beosztásúaknál továbbá olyan elemek is megjelentek, amik a többi csoportnál nem. Ilyen tényezők az emberek értékelése, ember központú kultúra és a vezető társak. Egyes vélemények szerint a vezetőség elkötelezettségének biztosítása azért is fontos, mert ők járulnak hozzá az alkalmazottak elkötelezettségéhez és csak egy elkötelezett vezető tudja elkötelezni a munkatársakat.

Összességében tehát az elkötelezettségnövelő tényezők, elégedettségi területek fontossága a vállalaton belül különböző szempontok alapján alkotott nagyobb csoportonként is változik. Éppen ezért az elkötelezettség erősítését célzó akciók előtt lényeges tisztázni, hogy kiket szeretne elkötelezni a vállalat, hiszen az eltérő munkavállalói csoportok eltérő programokat igényelhetnek.

\section{Elkötelezni - mi iránt?}

Az akciók megtervezése vagy bevezetése előtt szintén fontos lépés, hogy a vállalatok tisztázzák, hogy pontosan mi iránt akarják elkötelezni a dolgozókat, milyen viselkedést szeretnének tőlük elvárni. Melyik legyen az a terület, ahol (az elkötelezettség fennállása esetén) a munkavállalók az elvártnál több erőfeszítést akarjanak nyújtani. A vállalati céloktól függően, másra kell hangsúlyt fektetni.

Armstrong és Taylor (2014) szerint különbség van a között a vállalati programok és lépések között, ami a szervezeti elkötelezettség erősítéséhez, illetve ami a munkaköri/szakmai elkötelezettség erősítéséhez kell.

Szervezeti elkötelezettséget nagymértékű munkavállalói részvétellel, a döntésekbe történő bevonással, a véleménynyilvánításokra adott nagyobb szabadsággal lehet a leginkább növelni. A dolgozók számára fontos a tiszta jövőkép, illetve, hogy lássák, hogyan járulnak hozzá a vállalati eredményességhez, hiszen ekkor érzik, hogy a szervezet értékes, megbecsült tagjai és ekkor fognak kötődni a vállalathoz.

Szakmai elkötelezettség esetén a dolgozó jobban kötődik a hivatásához, mint magához a szervezethez. Így ezt a fajta elkötelezettséget a megfelelő munkakörtervezéssel, az érdekes és kihívásokkal teli munkával, a különböző készségek és képességek kipróbálására adott lehetőségek nyújtásával, tanulási és fejlődési programokkal, a fejlesztendő területekről való folyamatos visszacsatolással, valamint a feladatok elvégzése során nyújtott nagyfokú szabadsággal és önállósággal lehet a leginkább biztosítani.

\section{Az elkötelezettség erősítése}

A szakirodalom áttekintése után arra a véleményre jutottam, hogy elkötelezettséget nem lehet kialakítani, mivel az az egyénekben alakul ki. 
A Towers Perrin tanácsadó cég tanulmánya (2003) szerint az elkötelezettség építése egy véget nem érő folyamat, ami a jelentőségteljes és érzelmileg gazdagító munkakörnyezeten alapul. A CIPD (2012) szervezet véleménye alapján az elkötelezettség nem arról szól, hogy keményebb munkába hajszolja az embereket, hanem arról, hogy olyan körülményeket kell nyújtani, amiben ők hatékonyabban dolgoznak. (Armstrong, Taylor, 2014)

A szakirodalom alapján az elkötelezettség az egyénekben alakul ki, mozgatórugói pedig mind a munkahelyi élményekkel, tapasztalatokkal kapcsolatosak. Ebből következik, hogy ezeknek a területeknek a fejlesztése lehet az elkötelezettség erősítésének eszköze. A munkavállalók olyan környezetben lesznek elköteleződve, amik megfelelnek szükségleteiknek, ahol jól, fontosnak és értékesnek érzik magukat, ekkor nem csak hajlandóak lesznek elvárton felül dolgozni, de önként szeretnének is.

Mivel ez a környezet az emberi igényektől, érdekektől függ, azok pedig vállalatonként, munkaerőnként eltérőek, ráadásul a munkaerőn kívül számos egyéb tényező is befolyásolja a megfelelő környezet kialakítását úgy mint a vállalat tevékenysége, a munkaerő-piaci helyzete, mennyire bizonytalan, vagy biztos a gazdasági környezet, a vállalat pénzügyi helyzete, a vállalati méret, az mondható el, hogy nem létezik egy jó megoldás, általános aranyszabály a munkavállalói elkötelezettség erősítésére.

Azt azonban nem lehet állítani, hogy az elkötelezettség kialakulása csupán a szerencsén, vagy az erőforrásokon múlik, sem pedig azt, hogy a gazdaság egy funkciója. Számtalan olyan eszköz van a vezetők és a menedzsment kezében, amivel megteremthetik azt a környezetet, amiben elköteleződnek a munkavállalók, illetve biztosíthatják a tényezőket és elégedettségi területeket, amivel a már kialakult elkötelezettség erősíthető, illetőleg fenntartható. Ráadásul a legtöbbjükhöz még csak nem is erőforrásokra van szükség, sokkal inkább időre és odafigyelésre. Az elköteleződés ugyanis nem egyik napról a másikra alakul ki.

\section{Elégedettség növelő juttatások}

Mint ahogy azt már korábban írtam a juttatások önmagukban, közvetlenül nem alakítanak ki elkötelezettséget. Még akkor sem, ha azok a dolgozók igényeihez igazodnak. Egy munkavállaló nem fog csak azért az elvárton felül dolgozni vagy érzelmileg kötődni a szervezethez, mert jó juttatásokat kap. A megfelelő juttatások sokkal fontosabb szerepet játszanak a munkavállalók vonzásában és megtartásában.

Ugyanakkor azt sem állítható, hogy semmilyen kapcsolat nincs a két fogalom között. A juttatásokkal olyan elégedettségi területeket lehet növelni, amik erősítik a munkavállalói elkötelezettséget. Azok a juttatások fogják az elégedettséget és ez által közvetve az elkötelezettséget is erősíteni, amik a dolgozók számára fontosak, amik kielégítik a különböző szükségleteiket, amiket értékelnek. A munkavállalók természetesen eltérő igényekkel és érdekekkel rendelkeznek, felmérések alapján azonban elmondható néhány általánosság, preferencia.

Jól látható tehát, hogy a juttatásokkal számos elégedettségi területre lehet hatni. Ugyanakkor Poór (2013) szerint ezek nem folyamatosan növelik az elégedettséget, sokkal inkább egy általános elégedettségérzetet kelthetnek például belépésnél, vagy munkahelyek összehasonlításnál, ekkor ugyanis a jelentős összegű juttatások növelik a munkahely értékét. A juttatásoknak tehát sokkal fontosabb szerepük van a dolgozók vonzásában és megtartásában. Mivel nyújtásuk nem kötődik konkrét, elvárt teljesítményhez, gyakran megszokottá válhatnak és elvesztik elégedettség erősítő szerepüket. Éppen ezért a 
munkavállalói elkötelezettség erősítésének szempontjából csak a teljes körű javadalmazás koncepciójának megfelelően a többi kompenzációs elemmel összhangban éri el a kívánt hatást. Viszont ha ez sikerül, akkor a nyilvánvaló adózási- és költségmegtakarítási előnyökön túl további pozitívumok is származhatnak nyújtásukból.

\section{Összefoglalás}

A szakirodalom és a tanácsadó vállalatok által publikált felmérések és tanulmányok áttekintése és feldolgozása után arra a megállapításra jutottam, hogy a munkavállalói elkötelezettség, bár igen népszerű napjainkban, gyakran félreértelmezett, és tévesen használt fogalom. Sokszor keverik az elégedettséggel, motiváltsággal, illetőleg a dolgozók maradási szándékával. Számos definíció született meghatározására. Azok alapján az elkötelezettséget úgy fogalmaznám meg, mint a dolgozók önkéntes hajlandósága a maradásra, hűségre, illetve az elvárton felüli teljesítésre a vállalati siker és célok elérése érdekében. A szakirodalomban végül is egységes az a vélemény, hogy mindez hozzájárul a vállalatok üzleti eredményeihez. Ettől függetlenül nem állítom azt, hogy a munkavállalói elkötelezettség egy "Szent Grál”, egy minden problémát megoldó megoldás. Valóban szükséges és hasznos lehet a vállalati eredményesség és versenyképesség szempontjából, de önmagában nem jelenti, és nem garantálja azokat.

Ahogy a fogalom tartalmának és következményeinek körül közhelyek, úgy - véleményem szerint - a kialakítását illetően is sablonos megoldások élnek a köztudatban. Megítélésem szerint a „kialakítás” helyett a „kialakulás” megfelelőbb kifejezés. Valójában ugyanis, a vállalatok direkt módon nem tudnak munkavállalói elkötelezettséget kialakítani, mivel az kialakul, felmérések alapján a különböző munkahelyi tapasztalatok és élmények komplex hatására. A vállalatok tehát közvetve segítik a munkavállalók elkötelezettségének javulását, azáltal, hogy megteremtik azt a munkakörnyezetet, közeget, amiben a munkavállalók elkötelezettsége kialakulhat, és biztosítják azokat a tényezőket, amik a fenntartásához és erősítéséhez szükségesek.

Gyakorlatilag bármi, ami a munkahellyel vagy munkával kapcsolatos, szerepet játszhat az elköteleződés kialakulásában és befolyásolhatja fennmaradását. A különböző megközelítések integrálásával kilenc csoportba soroltam a szakirodalom által elkötelezettségnövelő tényezőknek nevezett területeket. Ezek a következők: jövőkép, lehetőségek, munka és feladatok, önrendelkezés, szociális környezet, kommunikáció, környezet, vállalati értékek és gyakorlatok, javadalmazás és elismerés. Az, hogy a tényezők közül melyek a legfontosabbak, egyénenként változó, ahogy az emberek szükségletei és igényei is eltérőek. A vállalatoknak belső kutatásokkal érdemes elemeznie, hogy a munkaerejének szempontjából melyek a fejlesztendő területek.

Felmérések alapján a dolgozók általában akkor válnak igazán elkötelezetté, ha a vállalat értékes és hasznos tagjának érzik magukat, látják, hogyan járulnak hozzá a vállalati sikerhez és célok eléréséhez. Ezen kívül, ha odafigyelnek véleményükre, beleszólhatnak a szervezeti múködésbe, továbbá érzik, hogy a vállalat valóban érdeklődik irántuk, törődik velük, elismeri a kiugró teljesítményüket és karrier előrelépési lehetőségekkel biztosítja jövőjüket akkor nagyobb az elköteleződés esélye. Az anyagi kompenzációs elemek, köztük a juttatások alapvetően nem tartoznak a legfontosabb elkötelezettségnövelő tényezők közé, sokkal lényegesebb feladatuk van a dolgozók vonzásában és megtartásában. 
Összességében tehát elmondható, hogy pusztán a juttatásokkal nem lehet munkavállalói elkötelezettséget kialakítani illetve növelni, mivel az elkötelezettség fogalmának és kialakulásának háttere ennél összetettebb.

Közvetve azonban a juttatások kapcsolatban állnak az elkötelezettséggel legalább három módon. Egyrészt munkavállalói elkötelezettség csak biztos környezetben alakul ki, az anyagi biztonságot pedig alapvetően a javadalmazási elemekkel, köztük a juttatásokkal lehet megteremteni. Másrészt a juttatásokkal erősíteni vagy gyengíteni lehet olyan elégedettségi területeket, amik befolyással vannak az elkötelezettségre. Erősítő területek többek között a munka-magánélet egyensúlya, egészséges életmód támogatása, a vállalati gondoskodás és törődés kifejezése, tehát bármi, ami a munkavállalók számára fontos és értékes. Míg elégedetlenség forrása a rosszul kialakított juttatási rendszer, a juttatások nem megfelelő kommunikálása, illetőleg a juttatások a közvélemény által megszokott szintjének elmaradása lehet. Harmadrészt a juttatások a teljes kompenzáció részét képezik. Az elemek egymással összhangban és az adott munkaerő szükségleteinek, igényeinek és érdekeinek megfelelő arányokban történő nyújtása elkötelezettségnövelő tényező lehet.

Azok a vállalatok tudnak igazán munkavállalói elkötelezettséget kialakítani és fenntartani, amelyek azt az egész vállalati működésük és emberi erőforrással kapcsolatos folyamatuk részévé teszik, és ebbe beletartoznak a juttatásokkal kapcsolatos döntések, juttatási stratégia megfelelő kialakítása is.

\section{Felhasznált irodalom}

- Aon Hewitt (2013): Managing Employee Engagement During Times of Change, https://www.aonhewitt.com.au/Home/Resources/Reports-and-research/ManagingEmployee-Engagement-During-Change-Report, Letöltve: 2015. január 13.

- Aon Hewitt (2014): 2014 Trends in Global Employee Engagement, http://www.aon.com/attachments/human-capital-consulting/2014-trends-in-globalemployee-engagement-report.pdf, Letöltve: 2015. március 30.

- Armstrong, M. - Murlis, H. (2005): Javadalmazás-menedzsment: Stratégia és gyakorlat, KJK KERSZÖV Jogi és Üzleti Kiadó, Budapest.

- Armstrong, M. (2006): A Handbook of Human Resource Management Practice, Kogan Page, London, GB.

- Armstrong, M., - Taylor, S. (2014): Armstrong's Handbook of Human Resource Management Practice, Kogan Page, London, GB.

- Bokor A. - Szőts-Kovács K. - Csillag S. - Bácsi K. - Szilas R. (2009): Emberi Erőforrás Menedzsment, Aula, Budapest.

- Koncz K. (2013): Karriermenedzsment, Budapest Corvinus Egyetem, Budapest.

- KPMG (2011): The real value of engaged employees, New thinking on employee engagement strategies, http://www.kpmg.com/BE/en/IssuesAndInsights/ArticlesPublications/Documents/re al-value-engaged-employees\%5B1\%5D.pdf, Letöltve: 2015. március 14.

- Poór J. (2013): Rugalmas ösztönzés, rugalmas juttatások, Wolters Kluwer, Budapest. 
- Storey, J. - Wright P. M. - Ulrich? D. (2009): The Routledge Companion to Strategic Human Resource Management, Routledge, London, GB.

- Towers Perrin (2003): Working Today: Understanding What Drives Employee Engagement, The 2003 Towers Perrin Talent Report, http://www.keepem.com/doc files/Towers Perrin Talent 2003\%28TheFinal\%29.pdf, Letöltve: 2015. március 14.

- Towers Perrin (2008): Closing The Engagement Gap: A Road Map for Driving Superior Business Performance, Towers Perrin Global Workforce Study 2007-2008, https://c.ymcdn.com/sites/www.simnet.org/resource/group/066D79D1-E2A8-4AB5B621-60E58640FF7B/leadership workshop 2010/towers perrin global workfor.pdf, Letöltve: 2015. március 14.

- Towers Watson (2012): Global Workforce Study, Engagement at Risk: Driving Strong Performance in a Volatile Global Environment, http://www.towerswatson.com/en/Insights/IC-Types/Survey-ResearchResults/2012/07/2012-Towers-Watson-Global-Workforce-Study, Letöltve: 2015. március 14.

- Truss, C. - Delbridge, R. - Alfes, K. - Shantz, A. - Soane, A. (2014): Employee engagement in theory and practice, Routledge, London, GB 